\title{
Implementasi Kegiatan Kepramukaan Terhadap Pembentukan Akhlak Peserta Didik Di SMP Kemala Bhayangkari 6 Kota Surabaya
}

\author{
Khoirul Anam \\ Universitas Sunan Giri Surabaya \\ *Email: kanam21@gmail.com
}

\begin{tabular}{|c|c|}
\hline Informasi Artikel & Abstrak \\
\hline $\begin{array}{l}\text { Diterima: } 12-07-2020 \\
\text { Disetujui: 26-11-2020 } \\
\text { Dipubikasikan: 26-02-2021 }\end{array}$ & $\begin{array}{l}\text { Penelitian ini bertujuan untuk melihat dan menakaraktifitas kepramukaan sebagai } \\
\text { salah satu pembentukan akhlak peserta didik. Sebagaimana amanah dalam } \\
\text { Undang-Undang Nomor } 20 \text { Tahun } 2003 \text { Tentang Sistem Pendidikan } \\
\text { Nasional, dikatakan bahwa Pendidikan Nasional berfungsi sebagai } \\
\text { pengembangan kemampuan dan pembentukan watak serta peradaban bangsa } \\
\text { yang bermartabat dalam rangka mencerdaskan kehidupan bangsa, bertujuan } \\
\text { untuk berkembangnya potensi peserta didik agar menjadi manusia yang } \\
\text { beriman dan bertakwa kepada Tuhan Yang Maha Esa, berakhlak mulia, } \\
\text { sehat, berilmu, cakap, kreatif, mandiri dan menjadi warga negara yang } \\
\text { demokratis serta bertanggung jawab. Adapun penelitian ini } \\
\text { menggunakan metode kualitatif naturalistik. Penelitian kualitatif adalah } \\
\text { wilayah kajian multimetode yang memfokuskan pada interprestasi dan } \\
\text { pendekatan naturalistik bagi suatu persoalan. Kajian ini akan meliputi berbagai } \\
\text { hal yang meliputi pengumpulan data lapangan seperti life history, pengalaman } \\
\text { pribadi, wawancara, pengamatan sejarah, teks visual dan sebagainya. } \\
\text { Pendekatan yang digunakan dalam penelitian ini adalah pendekatan } \\
\text { ethnometodology. Hasil penelitian mengatakan bahwa, Pertama, metode } \\
\text { pembelajaran yang digunakan dalam latihan rutin kepramukaan di SMP } \\
\text { Kemala Bhayangkari } 6 \text { Surabaya ialah learning by doing. Metode ini } \\
\text { memanfaatkan aktivitas lapangan dalam setiap bentuk letihanya. Selain } \\
\text { mendapatkan materi, peserta didik juga mendapatkan praktik secara langsung. } \\
\text { Kedua, dalam proses pembentukan akhlak peserta didik di SMP Kemala } \\
\text { Bhayangkari } 6 \text { Surabaya, Pembina pramuka memberikan contoh melalui setiap } \\
\text { perulakunya. Dalam hal ini Pembina Pramuka sebagai suri tauladan dari } \\
\text { seluruh peserta didik di SMP Kemala Bhayangkari } 6 \text { Surabaya. }\end{array}$ \\
\hline
\end{tabular}

Abstact
This study aims to see and measure scouting activities as one of the morals
formation of students. As mandated in Law Number 20 of 2003 concerning
the National Education System, it is said that National Education functions as
the development of capabilities and the formation of dignified national
character and civilization in order to educate the nation's life, aiming at
developing the potential of students to become faithful and human beings. be
devoted to God Almighty, have noble character, are healthy, knowledgeable,
capable, creative, independent and become democratic and responsible
citizens. This research uses naturalistic qualitative methods. Qualitative


research is a multi-method study area that focuses on interpretation and naturalistic approaches to a problem. This study will cover various things which include collecting field data such as life history, personal experiences, interviews, historical observations, visual texts and so on. The approach used in this study is the ethnometodology approach. The results of the study said that, First, the learning method used in routine scouting exercises at SMP Kemala Bhayangkari 6 Surabaya was learning by doing. This method makes use of field activity in every form of fatigue. In addition to getting material, students also get direct practice. Second, in the process of shaping the morals of students at SMP Kemala Bhayangkari 6 Surabaya, scout coaches provide examples through each behavior. In this case the Scout coach as role models for all students at SMP Kemala Bhayangkari 6 Surabaya.

\section{PENDAHULUAN}

Pendidikan merupakan salah satu pilar pokok dalam pembangunan bangsa. Tinggi-rendahnya derajat dan kedudukan bangsa dapat dilihat dari mutu pendidikan yang diterapkan. Pendidikan yang tepat dan efektif akan melahirkan anak-anak bangsa yang cerdas, bermoral, memiliki etos kerja dan inovasi yang tinggi. Seluruh negara yang telah berhasil mencapai kemajuan dalam penguasaan teknologi dan peradaban diawali dengan pemberian perhatian yang besar terhadap Pendidikan (MPP PKS, 2008).

Pada dasarnya pendidikan adalah suatu aktivitas untuk mengembangkan seluruh aspek kepribadian manusia yang berjalan seumur hidup. Dengan kata lain, pendidikan tidak hanya berlangsung di dalam kelas, tetapi berlangsung pula di luar kelas. Pendidikan tidak hanya bersifat formal juga nonformal. Secara substansial, pendidikan tidak sebatas pengembangan intelektualitas manusia atau diarahkan tidak hanya meningkatkan kecerdasan, melainkan mengembangkan seluruh aspek kepribadian manusia (Zuhairini dkk., 2004).

Di Indonesia Pendidikan ditempatkan pada posisi yang strategis. Hal ini dapat dilihat dalam Undang-Undang Republik Indonesia Nomor 20 Tahun 2003 Tentang Sistem Pendidikan Nasional Pasal 3 yakni, Pendidikan Nasional berfungsi mengembangkan kemampuan dan membentuk watak serta peradaban bangsa yang bermartabat dalam rangka mencerdaskan kehidupan bangsa, bertujuan untuk berkembangnya potensi peserta didik agar menjadi manusia yang beriman dan bertakwa kepada Tuhan Yang Maha Esa, berakhlak mulia, sehat, berilmu, cakap, kreatif, mandiri dan menjadi warga negara yang demokratis serta bertanggung jawab.

Begitu pula dengan agama Islam, Islam menganjurkan kepada umatnya untuk selalu menghiasi dirinya dengan akhlak yang baik. Bukan menganjurkan kepada perbuatan yang nista dan berakhlak buruk. Sungguh bukan merupakan keasingan bagi umatnya tatkala anjuran ini dijunjung tinggi, tapi sayangnya masih banyak dari umatnya mengabaikan dan mendustakan.

Pendidikan Islam juga dimaksdukan agar manusia mampu mengelolah dan menggunakan segala kekayaan yang ada di langit dan di bumi untuk kesejahteraan dan kebahagian hidup di dunia dan di akhirat kelak. Melalui proses pendidikan Islam diharapkan terciptanya Muslim yang beriman dan bertakwa keapada Allah, berakhlak mulia, beramal kebaikan (amal shaleh), mengusai ilmu (untuk dunia dan akhirat), 
mengusai keterampilan dan keahlian agar memikul amanah dan tanggung jwawab yang dibebankan kepadanya sesuai dengan kemampuan masing-masing.

Pedidikan agama Islam pada jenjang SMP/MTs merupakan penentu dalam perkembangan dan pembinaan rasa kemanusiaan yang adil dan beradab, maka pemahaman dan pengalamannya dengan tepat dan benar diperlukan untuk menciptakan kesatuan bangsa (Zakiyah Daradjat, dkk, 1992).

Pendidikan merupakan usaha sadar dan terencana untuk mewujudkan suasana belajar dan proses pembelajaran agar peserta didik secara aktif mengembangkan potensi dirinya untuk memiliki kekuatan spiritual keagamaan, pengendalian diri, kepribadian, kecerdasan, akhlak mulia, serta keterampilan yang diperlukan dirinya, masyarakat, bangsa dan negara.

Oleh karenanya penulis mengambil sebuah kesimpulan bahwa Pendidikan adalah suatu proses untuk menggali dan mengembangkan potensi peserta didik hingga menjadi mausia yang seutuhnya.

Pendidikan dapat ditempuh melalui beberapa jalur yakni formal dan non formal. Pendidikan formal dilaksanakan di sekolah dengan kurikulum dan kelembagaan yang terstruktur dengan rapi dan berlaku secara nasional. Sedangkan pendidikan non formal dilaksanakan di luar sekolah dengan kurikulum yang khas. Salah satu pendidikan non formal adalah kegiatan ekstra kurikuler.

Kegiatan ekstrakurikuler menjembatani kebutuhan perkembangan peserta didik yang berbeda, seperti perbedaan terhadap nilai moral dan sikap, kemampuan, serta kreativitas. Melalui partisipasinya dalam kegiatan ekstrakurikuler peserta didik dapat belajar dan mengembangkan kemampuan, berkomunikasi, bekerja sama dengan orang lain, menemukan dan mengembangkan potensinya. Dengan kata lain, kegiatan ekstrakurikuler dapat dijadikan sebagai sarana implementasi konsep pendidikan yang berorientasi kecakapan (life-skill oriented).

Tempat tujuan yang ingin dicapai dari pelaksanaan pendidikan yang berorientasi kecakapan hidup, yaitu (Departemen Pendidikan Nasional, 2005):

1. Mengaktualisasikan potensi peserta didik, sehingga dapat digunakan untuk mengatasi masalah yang dihadapinya;

2. Mengembangkan pembelajaran yang fleksibel, sesuai dengan prinsip pendidikan berbasis luas;

3. Mengoptimalkan pemanfaatan sumberdaya di lingkungan sekolah, sumberdaya yang ada di masyarakat, dan sesuai dengan prinsip manajemen berbasis sekolah; dan

4. Menyelenggarakan proses pendidikan di sekolah secara lebih terfokus kepada indikator keberhasilan dalam bentuk pencapaian dan penguasaan kecakapan hidup para peserta didik.

Salah satu kegiatan ekstrakurikuler yang berskala nasional dan diwajibkan oleh Kemendikbud adalah ekstrakurikuler Pramuka. Dasar pergerakan Pramuka dikenal dengan konsep TRISATYA sebagai janji setia, dan DHARMA PRAMUKA sebagai kewajiban anggota gerakan pramuka dalam bersikap serta berperilaku (Kwartir Nasional Gerakan Pramuka, 2013). 
Butir-butir dari Satya dan Dharma anggota Pramuka sarat dengan nilai-nilai akhlak mulia, seperti yang tertuang dalam dasa dharma: Taqwa kepada Tuhan YME, Cinta alam dan kasih sayang sesama manusia, Patriot yang sopan dan kesatria, Patuh dan suka bermusyawarah, Rela menolong dan tabah, Rajin terampil dan gembira, Hemat cermat dan bersahaja, Disiplin berani dan setia, Bertanggung jawab dan dapat dipercaya, dan Suci dalam pikiran perkataan dan perbuatan. Dengan demikian, upaya membina akhlak peserta didik dapat diwujudkan melalui pelaksanaan kegiatan Pramuka di sekolah.

SMP Kemala Bhayangkari 6 Kota Surabaya adalah salah satu sekolah yang menjalankan pendidikan kepramukaan. Peneliti terarik menjadikan sekolah ini sebagai obyek penelitian karena pendidikan kepramukaan di SMP Kemala Bhayangkari 6 Kota Surabaya menunjukkan prestasi yang cukup baik. dibanding Gudep-Gudep lainnya di kwartir cabang Surabaya.

Pendidikan Kepramukaan di SMP Kemala Bhayangkari 6 Kota Surabaya selalu mengarah pada kode etik gerakan pramuka yang sangat erat kaitannya dengan nilai keagamaan. Kegiatan kepramukaan yang dilakukan di sekolah tersebut selalu berorientasi pada pembinaan skill, Taqwa kepada Tuhan, cinta alam, kasih sayang, kesopanan, kepatuhan, bermusyawarah, keikhlasan, ketabahan, ketrampilan, kegembiraan, kesederhanaan, kecermatan, keprasahajaan, bertanggung jawab, suci dalam berfikiran, perkataan, dan perbuatan sebagai sarana untuk membina peserta didik SMP Kemala Bhayangkari 6 Kota Surabaya, untuk menjadi peserta didik yang berakhlak mulia.

Sebagai contoh, dalam kegiatan perkemahan selalu diisi dengan acara tazkijah (pensucian diri) pada malam hari. Hal ini terbukti efektif untuk membina akhlak peserta didik kearah terbentuknya akhlakuk karimah.

Karena penulis menemukan keterkaitan yang cukup erat antara pendidikan akhlak dan pendiidkan Kepramukaan di SMP Kemala Bhayangkari 6 Surabaya. Oleh sebab itu, terdapat dua rumusan masalah yang akan dijawab dalam penelitian ini. Pertama, Bagaimana konsep program kepramukaan di SMP Kemala Bhayangkari 6 Kota Surabaya? Kedua, Bagaimana pembentukan akhlak peserta didik pada program kepramukaan di SMP Kemala Bhayangkari 6 Kota Surabaya?

\section{METODE}

Penelitian tentang Pembentukan Akhlak Peserta didik Melalui Kegiatan Kepramukaan Di Sekolah Menengah Pertama Kemala Bhayangkari 6 Kota Surabaya menggunakan metode penelitian kualitatif naturalistik. Berdasarkan pendapat dari Denzin dan Lincoln (Endraswara, 2006). Penelitian kualitatif adalah kajian fenomena (budaya) empirik di lapangan. Penelitian kualitatif adalah wilayah kajian multimetode yang memfokuskan pada interprestasi dan pendekatan naturalistik bagi suatu persoalan. Kajian ini akan meliputi berbagai hal yang meliputi pengumpulan data lapangan seperti life history, pengalaman pribadi, wawancara, pengamatan sejarah, teks visual dan sebagainya.

Pendekatan yang digunakan dalam penelitian ini adalah pendekatan ethnometodology. Menurut Adam Kuper, sebagaimana dikutip Uhar Suharsaputra, etnometodologi adalah cabang ilmu sosiologi yang 
mempelajari berbagai upaya, langkah, dan penerapan pengetahuan umum pada kelompok komunitas untuk menghasilkan dan mengenali subjek, realitas, dan alur tindakan yang bisa dipahami bersama-sama. Pertanyaan besar yang diajukan oleh pendekatan ini adalah: Bagaimana orang memahami kegiatan seharihari mereka sehingga berperilaku dengan cara yang dapat diterima secara social (Uhar Suharsaputra, 2012).

\section{HASIL DAN PEMBAHASAN}

Pendidikan kepramukaan pada hakikatnya adalah merupakan salah satu ekstrakurikuler yang tidak bisa diabaikan lembaga pendidikan di Indonesia. SMP Kemala Bhayangkari 6 Kota Surabaya misalnya, di sekolah ini menurut observasi yang dilakukan peneliti Pendidikan kepramukaan suatu hal yang sangat penting untuk dipelajari dan dipahami serta diamalkan. Ini dapat dilihat dari Roster Pelajaran Tahun Ajaran 2019-2020 bahwa hampir semua kelas Pendidikan kepramukaan dilaksanakan.

Metode yang digunakan oleh para pembina di SMP Kemala Bhayangkari 6 Metode Pendidikan kepramukaan dilaksanakan dalam beberapa bentuk metode kegiatan sebagai berikut: (Program kegiatan ekstra SMP Kemala Bhayangkari 6 Kota Surabaya)

1. Pengamalan Kode Kehormatan Pramuka.

2. Belajar sambil melakukan (Learning by doing).

3. Sistem Beregu (patrol system).

4. Kegiatan menantang dan mengandung pendidikan sesuai perkem-bangan anggota muda.

5. Kegiatan di alam terbuka.

6. Sistem tanda kecakapan.

7. Sistem satuan terpisah untuk putera dan puteri.

Di SMP Kemala Bhayangkari 6 Kota Surabaya adanya usaha dalam pembentukan akhlak siswa/adik didik pelajaran Pendidikan Agama Islam pun tidak kala pentingnya, selain itu ada juga usaha dalam Pembinaan Akhlak peserta didik melalui kegiatan Kepramukaan. Bahkan pada hakikatnya di SMP Kemala Bhayangkari 6 Kota Surabaya ini lebih mengedepankan akhlak peserta didik, dari pada penguasaan pelajaran (kognotif). Syahrul, S.Pd selaku Kepala Sekolah SMP Kemala Bhayangkari 6 Kota Surabaya mengungkapkan sebagai berikut:

Metodenya melalui proses pembiasaan, dengan keteladanan, (dalam lingkungan sekolah), mempersiapkan program-program pembinaan karakter seperti Pramuka, Mentoring, jum'at berinfak, Shalat malam, zakat, kurban, penggalangan dana sosial, dan juga bercerita dengan kisah-kisah Nabi dan Rasul. Kemudian pada waktu pembelajaran boleh-boleh aja pembina memotong pembelajaran untuk memperbaiki sikap adik didik. Karna sikap adik didik lebih utama daripada nilia, kalua nilai dimana saja bisa mereka peroleh. (Wawancara dengan kepala sekolah) 
Senada dengan yang diungkapkan oleh pembina Pramuka bahwa metode yang dilakukan dalam Pembinaan Akhlak peserta didik yaitu:

Setiap latihan diadakan teori dilapangan maupun di kelas, kemudian dengan menggunakan metode uswah atau memberikan contoh, baik terkait dengan sikap, prilaku ataupun dalam tutur kata , metode pembiasaan disiplin secara langsung pada setiap latihan dan pada saat kegiatan (Wawancara dengan pembina).

Dari hasil wawancara tersebut peneliti menilai bahwa sebenarnya metode pembiasaan dilanjutkan dengan keteladanan atau uswah adalah salah satu metode andalan yang digunakan sekolah ini dalam pembinaan akhlak peserta didik. Hal ini dapat dibuktikan dengan bagaimana sekolah ini membuat kegiatan-kegiatan yang harus dilakukan secara kontiniutas (berkesinambungan). Seperti shalat Dhuha, Shalat Fardhu berjmaah, menyalami pembina dan teman ketika berjumpa dan sebagainya. Pembiasaan ini selain melatih diri sendiri menjadi pribadi yang siap, juga akan melatih mereka dapat berekspresi sesuai dengan kemampuan masing-masing. Yang tentunya itu semua didahului oleh sikap dan prilaku pembinanya.

Hal ini dikuatkan oleh orang tua peserta didik diwaktu peneliti disaat wawancarai. Yang mana beliau mengungkapkan:

Dengan metode pembiasaan, contoh keteladanan kemudian dengan memberikan hukuman bila berbuat salah, bisa dengan beristigfar, berzikir dan lain sebagainya,dapat memerikan efek jera dan yang paling fatal jika tidak mentaati dia nanti akan di boikot oleh kawan-kawannya (Wawancara dengan orang tua wali murid).

Adapun yang berkenaan dengan pembiasaan terhadap pelaksanaan ibadah maka hal ini sangat dianjurkan di dalam Islam. Selain mengajarkan ilmu pengetahuan kepada peserta didik juga hendaknya dibarengi untuk melatih mereka mengamalkan apa yang mereka ketahui. Pembiasaan yang diterapkan pembina bagi peserta didik adalah tindak lanjut dari apa yang sudah dipelajari dalam kehidupan peserta didik sehari-hari dan diharapkan mereka terbiasa melakukannya.

Selanjutnya mengenai metode pembinaan akhlak yang diterapkan pembina pramuka dan para guru di SMP Kemala Bhayangkari 6 ini adalah mendidik memulai dengan keteladanan/sistem among/uswah mendidik memulai dengan kedisiplinan, mendidik memulai dengan partisipasi, dan mendidik memulai dengan pembiasaan.

Mendidik melalui dengan memulai metode keteladanan atau yang lebih familier adalah sistem among. maksudnya adalah yang membina serta pembina pramuka yang lain akan menjadi contoh terlebih dahulu yang nantinya akan diikuti peserta didik, misalnya apabila peserta didik disuruh shalat maka pembina dan pembinanya juga ikut shalat, apabila peserta didik disuruh menutup aurat pembinanya juga harus menutup aurat, apabila peserta didik disuruh berpuasa pembina dan pembinanya juga harus berpuasa. 
Yang intinya apapun yang disuruh kepada peserta didik yang berkaitan dengan akhlak, maka pembina dan pembina harus ikut joga melakukannya.

Kemudian mendidik melalui kedesiplinan adalah ketika pembina sudah mengajarkan sesuatu pelajaran disekolah, maka pelajaran tersebut bisa dijadikan sebuah peraturan apabila dilanggar akan dikenakan sanksi. Mislanya adab makan yakni tidak bolah makan sambil berdiri. Ketika ada peserta didik yang makan sambil berdiri maka dia akan dikanakan sanksi. Juga seperti apel pagi, bagi peserta didik yang terlambat akan diasingkan dari barisan dan akan dapat sanksi dari pembinanya.

Kemudian dalam pembinaan Akhlak dikepramukaan sistem evaluasi dilakukan sekolah ini adalah melihat hasil laporan ibadah prestasi peserta didik dari laporan perkembangan sikap peserta didik dan perilaku peserta didik di lingkungan keluarga, lingkungan masyarakat dan lingkungan sekolah. Hal ini dapat dilihat hasil wawancara peneliti dengan guru bidang studi PAI adalah:

Dalam evaluasi pembinaan akhlak, kita menyampaikan hal apa yang harus dilakukannya, dilakukannya atau tidak, dan dengan melihat Laporan Perkembangan Sikap dan Perilaku Peserta didik dan juga Bidang Ibadah dan Prestasinya (Wawancara dengan guru PAI).

Hal ini senada yang disampaikan oleh Kepala Sekolah bahwa:

Setiap kegiatan atau hal yang dilakukan peserta didik itu diawasi dengan laporan. Setiap kegitan anak yang berhubugan dengan infak, shalat, sedekah, kurban ada laporannya, dan itulah nanti yang akan menjadi rujukan evaluasi. cuman dalam pengevaluasian belum utuh evaluasinya, masih butuh penyempurnaan (Wawancara dengan Kepala Sekolah).

Hal ini dapat dilihat dalam contoh laporan perkembangan sikap dan perilaku peserta didik serta bidang ibadah dan prestasi dalam lampiran tesis ini.

Dalam hasil wawancara peneliti dengan wali kelas bahwa evaluasi pembinaan Akhlak di SMP Kemala hayangkari 6 ini belum menentukan secara pasti seperti apa dan bagaimana kriteria atau tolak ukur dalam penilaian perkembangan akhlak peserta didik sehingga bisa dikatakan akhlak peserta didik tersebut Amat baik, Baik, kurang baik dan buruk. Sekolah ini hanya melihat laporan perkembangan sikap dan perilaku peserta didik serta bidang ibadah dan prestasinya. Apabila terdapat suatu perbuatan peserta didik yang kurang baik, maka wali kelas dan orang tua murid saling berkordinasi untuk menasehati anak yang bersangkutan.

Pendidikan merupakan satu hal yang tidak pernah terlepas dari kehidupan manusia, keberadaanya terintegrasi dalam kehidupan manusia itu sendiri. Setiap manusia pasti membutuhkan pendidikan, bahkan disadari atau tidak sesungguhnya manusia hidup itu selalu melakukan pendidikan di segala segi kehidupan dalam artian belajar. Oleh karena itu pada hakikatnya membahas persoalan pendidikan adalah suatu pembahasan yang sangat menarik. Apalagi membahas tentang pendidikan yang berkualitas atau yang tidak, pendidikan yang baik atau tidak baik, yang dapat dianggap berhasil atau tidak berhasil. 
Persoalan ini tentu harus didudukkan secara secara proporsional. Bila kita hendak melihat tingkat keberhasilan dari satu proses pendidikan yang dilakukan oleh sebuah lembaga pendidikan, maka terlebih dahulu kita harus paham tujuan dari pendidikan tersebut. Melihat ruang lingkupnya baik secara lingkup lembaganya, masyarakatnya maupun lingkup nasional, dan apa yang ingin dicapai dalam proses pendidikan yang dilaksanakan dalam satu lembaga tersebut.

Hal tersebut sebagaimana yang \dikatakan Imam Al-Ghazali bahwa akhlak itu perlu dididik, tanpa dididik akhlak tidak akan muncul dengan sendirinya dan akan menjadi baik. Dan untuk mendidik akhlak menurut al- Ghazali hal yang harus dilakukan adalah: Pertama adalah dengan cara mujahadah dan membiasakan dengan amal shaleh. Kedua adalah dengan melakukan perbuatan itu berulang-ulang sesuai dengan yang dikehendaki oleh akhlak yang baik tersebut (riyadhah).

Berdasarkan pertimbangan tersebut, dapat disimpulkan bahwa pembinaan akhlak yang baik dan mulia dalam dunia pendidikan adalah sesuatu hal yang mutlak dilaksanakan pada semua jenjang pendidikan. Dalam hal ini untuk mencapai tujuan dari pendidikan itu yakni pembinaan akhlak harus mempunyai metode dan strategi yang digunakan.

Adapun cara-cara mendidik yang bersifat pembinaan akhlak yang biasa dilakukan antara lain adalah:

a. Mendidik melalui keteladanan.

Kehidupan ini sebagian besar dilalui dengan saling meniru atau mencontoh oleh manusia yang satu pada manusia yang lain. Kecenderungam mencontoh sangat besar peranannya pada anak-anak, sehingga memberi pengaruh yang besar bagi perkembangan dan pertumbuhan pribadinya. Sesuatu yang dicontoh, ditiru atau diteladani itu mungkin yang bersifat baik dan mungkin pula bernilai buruk. Pembelajaran melalui keteladanan, sesungguhnya telah diuswahkan oleh Rasulullah dalam berbagai aktifitas kehidupan.

Pendidikan Islam yang dilaksanakan dan bahkan beliau sendiri adalah satu pribadi yang paling mulia dan paling layak dijadikan teladan bagi seluruh umat Islam sejak awal Islam hingga akhir zaman. Dalam proses pendidikan berarti setiap pendidik harus berusaha menjadi teladan anak (subjek) didiknya. Teladan dalam semua kebaikan dan bukan teladan dalam keburukan. Dengan keteladanan diharapkan anak didik akan mencontoh atau meniru segala sesuatu yang baik dalam perkataan dan perbuatan pendidiknya.

Rasulullah Saw sebenarnya sudah mencontohkan keteladanan dalam berdakwah Islam. Jika beliau bersalaman, maka beliau tidak akan menarik tangannya sebelum orang lain yang disalamnya tidak melepas tangannya. Beliau selalu menghadiri pertemuan para sahabatnya hingga usai. Beliau kepasar, membawa barang-barangnya sendiri dan berkata, aku adalah yang lebih berhak untuk membawanya. Beliau tidak merendahkan pekerjaan buruh, baik sewaktu membangun masjidnya yang mulia maupun 
sewaktu menggali parit. Beliau selalu memenuhi undangan orang merdeka, budak maupun hamba perempuan.

Iman Al-Ghazali mengatakan sebagaimana yang dikutip Hasan Asari salah satu dari tugas pembina adalah menjadi contoh teladan yang baik (uswab) bagi murid-muridnya. Praktik hidupnya mestilah sesuai dengan ajarannya. Hal ini sangat penting karena banyak orang yang lebih cepat memahami sesuatu dengan melihat ilustrasi praktis. Dia juga menegaskan bahwa kekeliruan tingkah laku pembina berakibat sangat besar tidak saja terhadap integritas pembina itu, tetapi juga potensial berpengaruh terhadap banyak orang yang mengikutinya sebagai model.

b. Mendidik Melalui Pembiasaan.

Dalam kehidupan manusia sehari-hari, banyak kebiasaan yang berlangsung otomatis dalam bertutur kata dan bertingkah laku. Berbagai kebiasaan harus dibentuk pada peserta didik oleh para pendidiknya, terutama pembina dan orangtuanya. Sejak kecil anak harus dibiasakan pada hal-hal yang positif. Demikian pembiasaan yang baik kepada anak, diharapkan akan memberi bekas positif pula pada diri peserta didik, dan akan menjadi bagian dan amalan bagi dirinya setelah dewasa kelak.

Sudah menjadi kenyataan pada diri manusia, bahwa manusia manapun yang hidup lama dalam lingkungan sesat dan rusak, dan masyarakat telah merasakan kejahatan dan pengrusakannya, kemudian datang ke seorang saleh yang menjadi temannya, sebagai pendidik yang berpengaruh dan membekas, sebagai juru dakwah yang tulus, yang memindahkan orang tersebut dari lumpur dosa dan nista ke taman kebahagiaan dari lingkungan kejahatan ke alam kemuliaan dan kebaikan, maka setelah ia hidup lama berkubang dosa, ia menjadi seorang mauttaqin terkemuka.

Ibnu Khaldun dalam bukunya Muqaddiman sependapat dengan al- Ghazali sebagaimana yang dikutip Nashih Ulwan bahwa anak akan tumbuh pada apa yang dibiasakan ayahnya kepadanya, tiadalah ia dapat ditundukkan akal tetapi kebiasaanlah yang dapat menundukkannya.

c. Mendidik melalui nasihat dan cerita.

Nasihat dan cerita merupakan cara mendidik yang mengandalkan bahasa, baik lisan maupun tertulis, dalam mewujudkan interaksi antara pendidikan dengan anak didik. Cara ini banyak ditemui dalam Al Qur-an, karena nasihat dan cerita pada dasarnya bersifat penyampaian pesan dari sumbernya kepada pihak yang memerlukan atau dipandang memerlukannya. Cerita atau nasihat tinggi nilainya dalam proses Pendidikan Islam, yang sepatutnya dipergunakan dalam usaha membantu dan mengarahkan anak didik, agar menjadi orang dewasa yang beriman dan mampu memanfaatkan waktu dalam mengerjakan sesuatu yang diridhai Allah, untuk mengejar keselamatan, kebahagiaan dan kesejahteraan di dunia dan akhirat.

Menurut Nashih Ulwan dalam bukunya Tarbiyatul Aulad Fil Islam terjemahan Sifullah Kamalie mengatakan bahwa metode Alquran dalam menyajikan nasihat dan pengajaran mempunyai ciri tersendiri yakni: 
1. Menyeru Untuk Memberikan Kepuasan dengan Kelembutan atau Penolakan. Metode ini mempunyai pengaruh yang sangat besar terhadap jiwa dan perasaan. Metode untuk memberi kepuasan menolak atau mengasihani ini teramat nyata dalam dialog Alquran dengan hati dan akal manusia, dengan berbagai bentuk, jenis dan tingkatannya, atau ucapan para Nabi dan para dai.

2. Metode cerita dengan Disertai Tamsil Ibarat dan Nasihat Metode ini mempunyai pengruh tersendiri bagi jiwa dan akal, dengan mengemukakan argumentasi yang logis.

3. Pengarahan alquran dengan wasiat dan nasehat

d. Mendidik melalui metode latihan, yaitu dilakukan dengan menyuruh anak didik mengerjakan sesuatu secara berulang-ulang.

Misalnya dalam pengajaran mengaji (membaca Al Qur-an) yang harus diulang, di samping itu untuk menimbulkan kebiasaan praktis dalam melaksanakan sholat lima waktu, orang tua atau pembina tidak boleh bosan-bosannya mengingatkan dan melatih anak-anaknya, karena jika sesuatu dilakukan secara berulang-ulang akan menjadi mudah melaksanakannya sekaligus akan menjadi kebiasaan hidupnya.

Dalam metode latihan ini tokoh-tokoh Islam sebenarnya sudah lama mengajarkannya. Imam Al-Ghazali misalnya, menyarankan pembina untuk mengirim murid yang sombong pergi kepasar dan mengemis, dan merasa kehinaan sebagai seorang pengemis, kesombongan akan hilang sedikit demi sedikit.

e. Metode demonstrasi, yaitu proses belajar mengajar yang dilakukan pembina atau orang lain yang khusus meminta peserta didik, memperlihatkan sesuatu proses pada sejumlah murid di dalam sebuah kelas.

Misalnya bagaimana proses mengerjakan wudhu' sebelum sholat, tata cara sholat lima waktu, tata cara berdo'a, tata cara dan sopan santun makan yang Islami, dan lain-lain yang memerlukan pendemonstrasian dalam pembelajaran.

Beberapa cara mendidik yang telah dikemukakan di atas tidak berdiri sendiri secara terpisah. Penggunaan metode mendidik dapat dilakukan bersama-sama dan saling mendukung satu dengan yang lain. Semua ini menuntut kebijaksanaan para pendidik dalam menerapkannya, karena satu cara mungkin efektif bagi anak tertentu, namun belum tentu efektif untuk anak yang lain.

Pramuka merupakan salah satu organisasi yang dikelola secara sistematis dan terstruktur. Sistematis berarti kegiatan-kegiatan dalam ke-pramukaan telah tersusun sesuai dengan jenjang-jenjang keilmuan dan kemampuan. Sedangkan terstruktur dapat diartikan sebagai sebuah organisasi yang memiliki tatanan kepengurusan secara vertikal fungsionaris. Di Indonesia keberadaan organisasi pramuka telah terlegitimasi dalam Undang-Undang Nomor 12 Tahun 2010 tentang Gerakan Pramuka. Dengan adanya 
undang-undang tersebut menjadikan gerakan pramuka sebagai salah satu organisasi yang dipercaya mampu mengembangkan potensi diri serta membentuk akhlakul karimah bagi setiap generasi muda.

Kegiatan ke-pramukaan merupakan salah satu kegiatan yang mengutamakan aspek kedisiplinan dan kekompakkan. Disiplin tidak boleh diartikan secara sempit harus mengikuti setiap kegiatan tepat waktu. Melainkan, disiplin harus diartikan secara luas dalam konteks kehidupan sehari-hari. Misalnya, disiplin dalam belajar, disiplin dalam membantu orang tua, disiplin dalam beribadah, dan lain sebagainya. Oleh karenanya, disiplin tak jauh bedanya dengan istilah istiqomah dalam agama Islam. Selain itu, setiap anggota pramuka juga dituntut untuk mencerminkan perilaku kompak. Sama halnya dengan disiplin, kompak juga harus diartikan secara luas dengan praktik kehidupan sehari-hari. Misalnya, membantu orang yang membutuhkan pertolongan, ikut serta kegiatan kemasyarakatan, dan lain sebagainya. Oleh karena itu, kompak merupakan cerminan dari sifat gotong-royong yang merupakan nilai-nilai Pancasila.

Jika kita melihat tujuan dibentuknya organisasi pramuka dalam ketentuan Pasal 4 UU No. 12 Tahun 2010 tentang Gerakan Pramuka, dikatakan bahwa "Organisasi pramuka bertujuan untuk membentuk setiap anggota pramuka memiliki kepribadian yang beriman, bertaqwa, berakhlak mulia, berjiwa patriotik, taat hukum, disiplin, menjunjung tinggi nilai- nilai luhur bangsa, dan memiliki kecakapan hidup sebagai kader bangsa dalam menjaga dan membangun Negara Kesatuan Republik Indonesia, mengamalkan Pancasila, serta melestarikan lingkungan hidup. Dalam perjalananya tujuan ini harus dapat diimplementasikan terhadap setiap kegiatan-kegiatan ke-pramukaan secara periodik.

Selama kurun waktu lebih dari dua puluh sembilan tahun penulis telah terjun secara langsung dalam proses pembinaan peserta didik. Selama kurun waktu itu pula, menemukan ragam karakter dan perilaku peserta didik. Kemajemukan karakter peserta didik itulah membuat Pembina harus memiliki kemampuan yang baik serta keeladanan atau uswah. Kemampuan tidak hanya diukur seberapa ahli seorang Pembina memahami tentang teori-teori ke-pramukaan, melainkan juga harus barbarengan dengan praktik dan keluesan dalam melatih. Hal ini sangat penting guna memahami setiap pola dan karakteristik setiap peserta didik. Karena dalam keadaan tertentu tidak bisa disamakan antara peserta didik yang satu dengan peserta didik yang lain.

Setiap Pembina pramuka memang diwajibkan untuk memahami tujuan dari dibentuknya organisasi pramuka. Kewajiban ini diperlukan agar setiap Pembina pramuka berfungsi sebagai katalisator pembentuk kepribadian peserta didik sesuai dengan tujuanya. Sehingga dalam hal ini, keberadaan Pembina pramuka menjadi sangat fundamental dalam pembentukan karakter peserta didik yang berakhlakul karimah.

Dalam proses pembinaan, pembina berupaya untuk mewujudkan tujuan-tujuan tersebut. Pembina sangat menyadari bahwa perkembangan teknologi saat ini telah berdampak pada pola pikir setiap peserta didik. Tentu pola pikir tersebut juga memengaruhi perilaku dalam kehidupan sehari-hari. Oleh karenanya, dalam mekanisme pembinaan penulis condong terhadap kegiatan yang bersifat kedisiplinan (istiqomab) serta keteladanan (uswah) melalui praktik kehidupan sehari-hari. Baik Dwi Satya, Dwi Dharma, Tri Satya, dan 
Dasa Dharma tidak hanya penulis bebankan kepada peserta didik untuk menghafal. Melainkan, penulis sebagai Pembina berkewajiban untuk menjelaskan nilai-nilai yang terkandung di dalamnya dan bahkan harus diberikan contoh dalam praktik kehidupan sehari-hari.

Namun tidak bisa dipungkiri bahwa perbandingan jumlah Pembina dalam setiap sekolah (Gugusdepan) tidak proporsional dengan jumlah peserta didik. Bahkan dalam beberapa sekolah (Gugusdepan) satu Pembina berkewajiban untuk membina lebih dari 50 (lima puluh) orang, padahal idealnya sesuai dengan AD ART Gerakan Pramuka satu orang Pembina maksimal membina 6 (enam) s.d 10 (sepuluh) peserta didik untuk golongan siaga dan 7 (tujuh) s.d 10 (sepuluh) peserta didik untuk golongan penggalang. Namun kondisi demikan bukan untuk dihindari atau bahkan dipermasalahkan, sebagaimana yang penulis sampaikan diawal bahwa seorang Pembina harus memiliki keluesan dalam memahami setiap karakteristik peserta didik, sehingga dapat menyampaikan hal-hal yang bersifat fundamental untuk menjadikan setiap peserta didik menjadi generasi yang tangguh dan berakhlakul karimah.

Berikutnya ialah penanaman kecintaan terhadap pramuka bagi setiap peserta didik. Kecintaan terhadap pramuka menjadi sangat penting bagi generasi muda, semakin cinta kepada pramuka akan semakin berwujud pula pemikiran yang matang dan karakter yang berakhlakul karimah. Hal ini didasarkan terhadap asumsi, bahwa semakin cinta seseorang terhadap sesuatu, maka semakin penasaran pula seseorang terhadap sesuatu tersebut. Rasa penasaran tersebut tentu akan selalu dicari beriringan dengan setiap kegiatan-kegiatan yang ia ikuti. Oleh sebab itu, penulis dalam melakukan makanisme pembinaan selalu memberikan porsi untuk memotivasi para peserta didik.

Motivasi tersebut penulis berikan dalam bentuk contoh-contoh konkrit kegiatan yang penulis pernah ikuti selama menjadi peserta didik. Selain itu, penulis juga memberikan gambaran kegiatan tersebut, bahkan cerita-cerita menarik yang tentu berbau iming-iming agar rasa penasaran tersebut semakin menguat. Karena penulis yakin dalam setiap kegiatan ke-pramukaan semuanya mengandung nilai-nilai luhur yang sesuai dengan pri- kemanusiaan. Oleh karenanya, dengan terbatasnya waktu dalam membina, penulis sebagai Pembina sangat yakin bahwa dengan memberikan motivasi dan menumbuhkan rasa kecintaan terhadap pramuka, peserta didik akan mengikuti kegiatan-kegiatan pramuka pada jenjang-jenjang berikutnya.

Dan pada akhirnya, harus diakui memang tidak semuanya peserta didik dapat tumbuh berkembang sesuai dengan harapan seorang Pembina. Malahan tidak jarang dalam satu kelas tidak lebih dari 30\% yang memiliki rasa cinta terhadap pramuka. Namun bagi seorang pembina, terdapat 8 (sepuluh) dari 30 (tiga puluh) orang yang memiliki kecintaan terhadap pramuka sudah menjadi kebanggan yang luar biasa. Dan semoga seluruh peserta didik yang pernah dibina dan dilatih oleh penulis kelak menjadi orang yang berkarakter baik dan berakhlakul karimah. 


\section{KESIMPULAN}

Berdasarkan pembahasan di atas, maka dapat diambil kesimpulan bahwa konsep program kepramukaan di SMP Kemala Bhayangkari 6 Kota Surabaya adalah learning by doing belajar sambil melakukan. dilakukan melalui praktek secara praktis sebanyak mungkin. Mengarahkan perhatian peserta didik untuk melakukan hal kegiatan yang nyata, serta merangsang rasa keingintahuan terhadap hal - hal baru dan keinginan untuk berpartisipasi dalam segala kegiatan, tidak hanya melaksanakan teori melulu akan tetapi langsung umtuk melakukan. Selain itu, pembentukan akhlak peserta didik pada program kepramukaan di SMP Kemala Bhayangkari 6 Kota Surabaya adalah memberikan suri tauladan yang di awali oleh para pembina pembina dan kepala sekolah. Suri tauladan ini di dalam kepramukaan leih dikenal dengan sistem among ibarat suatu kendaraan dalam melaksanakan metode kepramukaan, dalam gerakan pramuka hubungan peserta didik dengan pembina seperti hubungan kemitraan yang berlandaskan kesuka relaan, saling percaya, saling menghormati, saling menghargai, saling asah asih asuh. Pembina pramuka sebagai orang dewasa mendengarkan aspirasi serta kebutuhan peserta didik dan menggabungkan diri dengan peserta didik dalam hidupnya selama proses pendidikan. Dalam proses pendidikan pembina harus dapat mengembangkan akat dan minat peserta didik aik moral, spiritual, mental, fisik, intelektual, emosional maupun sosial peserta didik untuk mengarah kepada karakter yang berakhlak dalam berkehidupan di masyarakat.

\section{DAFTAR PUSTAKA}

Departemen Pendidikan Nasional. 2005. Konsep Pendidikan Berorientasi Kecakapan Hidup. Jakarta: Dirjen Dikdasmen. Departemen Pendidikan Nasional.

Endraswara. 2006. Metode, Teori, Teknik, Penelitian Kebudayaan: Ideologi, Epistemologi dan Aplikasi. Yogyakarta: Pustaka Widyatama.

Kwartir Nasional Gerakan Pramuka, Gerakan Pramuka: Anggaran Dasar dan Anggaran Rumah Tangga Berdasarkan Keputusan Musyawarah Nasional Gerakan Pramuka Nomor: 11/Munas/2013. Jakarta: Kwarnas Gerakan Pramuka.

MMP PKS. 2008. Memperjuangkan Masyarakat Madani. Jakarta: MPP PKS.

Program kegiatan ekstra SMP Kemala Bhayangkari 6 Kota Surabaya

Uhar Suharsaputra. 2012. Metode Penelitian Kuantitatif, Kualitatif dan Tindakan. Bandung: Refika Aditama.

Zuhairini dkk. 2004. Filsafat Pendidikan Islam. Jakarta: Bumi Aksara.

Zakiyah Daradjat dkk. 1992. Ilmu Pendidikan Islam. Jakarta: Bumi Aksara. 